\title{
PRODUKTIFITAS PENGELOLAAN WAKAF DI KECAMATAN LICIN KABUPATEN BANYUWANGI
}

\author{
Oleh: \\ Ahmad Khoirin Andi \\ STIS Al Maliki Bondowoso, Indonesia \\ ahkhanme@gmail.com
}

\begin{abstract}
:
Wahbah Zuhaili said that Syari'ah principles is to realize the purpose of generation actually in creating happiness of individual and jama'ah, carrying out and cele brating the world with an infrastructures wich will present to proccess of the perfectness, kindness, wifure and civiitation. The purpose of reserch is to know on how the productivity practice in managing wakaf wealth in Licin Sub district, Banyuwangi Regency.
\end{abstract}

Keyword: Review Islamic Law, Wakaf, Syari'ah

\section{A. Pendahuluan}

Keberlakuan hukum Islam di Indonesia tidak bisa dicerai-pisahkan dari lembaga Peradilan Agama. ${ }^{1}$ Menurut istilah, Cik Hasan Bisri ${ }^{2}$ memberikan pengertia bahwa peradilan adalah badan atau organisasi yang diadakan negara untuk mengurusi dan mengadili perselisihanperselisihan hukum. Adanya Peradilan sebagai salah satu lembaga yang bertugas menyelesaikan urusan masyarakat adalah fardhu kifayah yakni kegiatan bersama yang erat sekali hubungannya dengan keimanan.

Di negara kita, badan-badan peradilan sebagai mana dimaksud sesuai dengan ketentuan Undang-undang Nomor 4 Tahun 2004 bahwa kekuasaan kehakiman dilaksanakan oleh Peradilan Umum, Peradilan Agama, Peradilan Tata Usaha Negara, Peradilan Militer dan di bawah Mahkamah Agung. Semua lembaga peradilan yang berada di Indonesia tentunya secara umum tidak bertentangan dengan hukum Islam. Meskipun ada - tertentu yang bertolak belakang dengan ajaran Islam. ini dikarenakan pijakan dasar Undang-undang Indonesia mengadopsi

${ }^{1}$ Amin Suma M, 16, dikutip dari Kata Sambutan Direktur Pembinaan Peradilan Agama Bapak Wahyu Widiana.

${ }^{2}$ Abdullah Tri Wahyudi, Peradilan Agama di Indonesia, (Yogyakarta: Pustaka Pelajar, Cet. I, 2004), 1. Mengutip dari Cik Hasan Bisri, Peradilan Islam dalam Tatanan Masyarakat Indonesia, (Bandung, Remaja Rasdakarya, 1997), 2. 
warisan Undang-undang Kolonial Belanda. Akan tetapi secara umum tujuanya tidak bertentangan dengan syariat Islam.

salah satu spirit didalam Islam yang terkandung yakni spirit ekonomi. Islam memiliki bentuk dan konsep ekonomi yang berbeda dengan konsep ekonomi kapitali dan sosialis. System ini disebut ekonomi Islam. Didalam sistem ekonomi Islam, satiap manusia diberi kebebasan untuk mengelola hartanya. Akan tetapi dalam pengelolaannya ada sebagian dari hartanya harus dikeluarkan sebagai infak untuk orang yang membutuhkan. Dalam Al Qur'an, tujuan sistem demikian termasuk dari tujuan distribusi ekonomi yang penjelasannya dapat ditemukan pada Qs. az- Zariyat (51:19) kekayaan mereka terdapat hak bagi peminta-minta dan orang yang terang. ${ }^{3}$ Tujuannya adalah agar harta kekayaan tidak hanya beredar dikalangan rang kaya. (QS. al-Hasyr [59]:60), ayat tersebut diperkuat oleh QS. at-Taubah (9:60). Salah satu bentuk penyaluran harta yang paling baik adalah penyaluran harta wakaf.

Mengapa demmikian, Wakaf sebagai perangkat ekonomi yang penting dan mendapat porsi perhatian serius dalam diskursus fiqh Islam, sebagai upaya menjembatani dan mengembalikan relasi/interaksi dalam masyarakat. tidak diragukan lagi bahwa manajemen wakaf terkait langsung dengan prilaku atau trend perekonomian bagi seorang muslim dalam meanstream umum bagi aktifitas kemanusiaan secara kolektif dan mengandung acuan yang jelas tentang teknis bagaimana seorang hamba berinteraksi dengan penciptanya dalam bingkai keimanan dan etika. Dengan demikian Nampak bahwa nilai-nilai Islam mampu menggerakkan roda kegiatan perekonomian menuju kemaslahatan umum. ${ }^{4}$

Tata cara pengelolaan wakaf dalam Islam telah diatur berdasarkan Alquran dan Sunah Rasulullah SAW. Harta wakaf, menurut ajaran Islam, hanya diambil manfaatnya, sementara barang asalnya harus tetap. Karena itu, harta wakaf tidak boleh dijual, dihibahkan, atau diwariskan. Pada prinsipnya, menurut John L Esposito dalam Ensiklopedi Oxford: Dunia Islam Modern, pembuat wakaf menentukan bentuk pengelolaan wakafnya sendiri. Pengelola wakaf biasa disebut dengan istilah mutawalli atau nadhir.

Dalam sejarah Islam lembaga ini telah memainkan peran ekonomi dan sosial yang teramat penting. Secara tradisional institusi ini berfungsi

3 Nawawi Thabrani, Dinamikan Perwakafan dalam Peradaban Islam. (Jember: Pustaka Radja. Cet-1. 2013), 2.

4 Ahmad Muhammad sa'ad, al-Malamih al-Asasiyah lil alaqah Baina NidzamialWaqf wa-Iqtishad (pengantar Teori).

310 JURNAL LISAN AL-HAL 
sebagai sumber pembiayaan bagi masjid-masjid, sekolah-sekolah, pengkajian dan penelitian, rumah sakit, pelayanan sosial dan pertahanan. ${ }^{5}$ Amalan ibadah wakaf telah dilaksanakan semenjak zaman Rasulullah saw. Sedangkanpada masa Khulafa ar-Rasyidin, wakaf terus diamalkan, kemudian secara berkelanjutan diamalkan pula oleh umat Islam di berbagai negarahingga sekarang ini.

\section{B. Pengertian Wakaf dan Rukunnya}

Wakaf berasal dari bahasa arab "Waqafa-Yaqifu-Waqfan"yang berarti menahan, berhenti, tetap, berdiri, atau diam di tempat. Kata ini sering disamakan dengan kata "Habasa-Yahbisu-Tahbîsan". ${ }^{6}$ Secara terminologi, wakaf didefinisikan berbeda-beda oleh para imam madzhab. Menurut Hanafi, wakaf didefinisikan dengan:

$$
\text { الوقف هو حبس العين على حكم ملك الوقف والتصدق بالمنفعة جهة الخير } 7 \text { و }
$$

"Menahan suatu komoditas (aset) dengan tetap pada kepemilikan orang yang mewakafkan dan mendistribusikan manfaatnya untuk kepentingan kebaikan"8

Definisi yang dikemukakan oleh Hanafi ini berimplikasi pada aset wakaf yang kepemilikannya tidak hilang secara mutlak, dan dengan demikian maka wakif berhak untuk menjual dan menariknya kembali. Selain itu, ini akan mengakibatkan kepemilikan harta wakaf menjadi milik hak waris jika si wakif meninggal dunia.

Definisi berbeda dikemukakan oleh mazhab Maliki, yaitu:

جعل المالك مفعة مملوكة ولو كان مملوكا باج اوجعل غلته كدراهم لمستحق بصيغة مدة ما يراه المخبس 9

"Menyerahkannya seorang pemilik aset pada manfaat atas aset yang dimiliki dengan akad sewa atau transaksi atau menyerahkan capital aset tersebut, seperti dirham (mata uang) kepada orang yang berhak dengan sighat selama masa waktu yang dikehendakinya"10.

Madzhab Maliki berpendapat bahwa wakaf itu tidak berarti melepaskan harta yang diwakafkan dari kepemilikan orang yang

5 Muhammad Akram Khan , An Introduction to Islamic Economics (Pakistan : IIIT danInstitute of Policy Studies, 1994), 82-83.

${ }^{6}$ Direktorat Jenderal Bimbingan Masyarakat Islam Departemen Agama RI. Fiqh Wakaf. (Jakarta: Departemen Agama, 2007), 1. Dikutip dari Muhammad al-Khathib, alIqna. Beirut: Darul Ma'rifah, 26.

${ }^{7}$ Wahbah Zuhaily, Fiqh Al-Islam Wa Adillatuhujuz 10, (Damaskus: Daar el-Fikr, 2006), 7599.

${ }^{8}$ Suhrawardi K. Lubis, dkk, Wakaf..., 4.

${ }^{9}$ Wahbah, Fiqh al-Islam..., 7602.

10 Direktorat Jenderal, Fiqh Wakaf, 3. 
mewakafkan. Dengan demikian, kepemilikan atas aset wakaf masih berada pada wakif, karena yang diwakafkan hanyalah manfaatnya saja, bukan substansi materinya. Perwakafan dalam madzhab Maliki berlaku untuk suatu masa tertentu, dan tidak bersifat eternal.

Adapun imam As Syafi'i dan imam mengemukakan pendapat bahwa yang dimaksud wakaf adalah:

"Menahan aset yang dapat dimanfaatkan dengan melanggengkan substansinya dengan memutus kewenangan distributif dari pihak wakif atau yang lain untuk mendistribusikan yang diperkenankan atau mendistribusikan hasilnya untuk kepentingan kebaikan guna mendekatkan diri kepada Allah"11.

Pengertian tersebut menjelaskan ketegasan terhadap status kepemilikan harta wakaf yang tidak lagi menjadi milik orang yang mewakafkan. Karena apabila akad wakaf sah, menurut pengertian tersebut, maka kepemilikan harta wakaf menjadi milik Allah, dengan artian bahwa harta wakaf tersebut bukan lagi milik wakif, melainkan milik umat, dan dengan demikian maka putuslah kepemilikan si wakif terhadap harta tersebut.

Dari beberapa pengertian tersebut, maka dapat dipahami hakikat dari sebuah tindakan perwakafan adalah menyedekahkan harta yang dimiliki untuk digunakan sebagai kemaslahatan untuk kepentingan bersama. ini sebagaimana yang tercantum juga dalam pasal 4 dan 5 Undang-Undang Nomor 41 Tahun 2004 tentang tujuan dan fungsi wakaf yang menyatakan bahwa wakaf bertujuan memanfaatkan harta benda wakaf sesuai dengan fungsinya, yaitu mewujudkan potensi dan manfaat ekonomis harta benda wakaf untuk kepentingan ibadah dan untuk memajukan kesejahteraan umum ${ }^{12}$.

Sedangkan pengertian wakaf menurut peraturan perundangundangan yang berlaku di Indonesia adalah sebagai berikut:

a. Peraturan Pemerintah No. 28 tahun 1977 Wakaf adalah perbuatan hukum seseorang atau badan hukum yang memisahkan sebagian dari harta kekayaannya yang berupa tanah milik dan kelembagaannya untuk selamalamanya untuk kepentingan atau keperluan umat lainnya sesuai ajaran Islam. ${ }^{13}$

b. Wakaf dalam Kompilasi Hukum Islam (KHI) Wakaf adalah perbuatan hukum seseorang atau kelompok orang atau badan hukum yang

11 Wahbah, Fiqh al-Islam..., 7601

12 Undang-Undang Nomor 41 Tahun 2004 tentang Wakaf.

13Peraturan Pemerintah Nomor 28 Tahun 1977 tentang Wakaf

$312 \mid$ JURNAL LISAN AL-HAL 
memisahkan sebagian dari benda miliknya dan kelembagaannya untuk selam-lamanya guna kepentingan ibadah atau keperluan umum lainnya sesuai ajaran Islam. ${ }^{14}$

c. Undang-undang Wakaf Nomor 41 Tahun 2004 dan Peraturan Pemerintah Nomor 42 Tahun 2006 Wakaf adalah perbuatan hukum wakif untuk memisahkan dan/atau menyerahkan sebagian harta benda miliknya untuk dimanfaatkan selamanya atau untuk jangka waktu tertentusesuai dengan kepentingannya guna keperluan ibadah dan atau kesejahteraan umum menurut syariah. ${ }^{15}$

Menurut jumhur ulama dari mazhab Syafi'i, Maliki dan Hanbali, mereka sepakat bahwa rukun wakaf ada empat, ${ }^{16}$ yaitu:

1. Wakif (orang yang berwakaf)

2. Mauquf 'alaih (orang yang menerima wakaf)

3. Mauquf (harta yang diwakafkan)

4. Sighat (pernyataan wakif sebagai suatu kehendak untuk mewakafkan harta bendanya).

Menurut pasal 6 Undang-undang Nomor 41 Tahun 2004, wakaf dilaksanakan dengan memenuhi unsur wakaf sebagai berikut: ${ }^{17}$ Wakif, Nadzir, Harta Benda Wakaf, Ikrar Wakaf, Peruntukkan Harta Benda Wakaf, dan Jangka Waktu Wakaf.

Menurut hukum (fiqih) Islam, wakaf baru dikatakan sah apabila memenuhi dua persyaratan, yaitu:

1. Tindakan/perbuatan yang menunjukan pada wakaf.

2. Dengan ucapan, baik ucapan (ikrar) yang sharih (jelas) atau ucapan yang kinayah (sindiran). Ucapan yang sharih seperti: "Saya wakafkan....". Sedangkan ucapan kinayah seperti: "Saya shadaqahkan, dengan niat untuk wakaf".

\section{Produktifitas Pengelolaan Wakaf di Kecamatan Licin}

Licin adalah sebuah kecamatan di Kabupaten Banyuwangi, Provinsi Jawa Timur, Indonesia. Kecamatan ini awalnya termasuk bagian dari Kecamatan Glagah, Kabupaten Banyuwangi. Sebuah kecamatan yang letaknya jika dilihat hari ini berada di sebelah timur kecamatan Licin dan

\footnotetext{
${ }^{14}$ Kompilasi Hukum Islam tentang Wakaf.

15Undang-Undang Nomor 41 Tahun 2004 tentang Wakafdan Peraturan Pemerintah Nomor 42 Tahun 2006.

16 Ali, Muhammad Daud, 1998, Sistem Ekonomi Islam Zakat dan Wakaf, Jakarta: UI Press.

17M. Zein, Satria Effendi, 2004, Problematika Hukum Keluarga Islam Kontemporer, cet. I, Jakarta: Kencana.
} 
disebelah Barat Kota Banyuwangi. Melihat area yang cukup luas dari kecamatan Glagah dan Licin dirasa mampu mengembangkan potensi daerah dan adat setempat maka dilakukanlah pemekaran berdasarkan Peraturan Daerah No. 31 Tahun 2004.

Setelah dilakukannya pemekaran kemudian Kecamatan Licin Dibagi Menjadi Delapan Desa. Diantaranya adalah; Desa Banjar, Desa Gumuk, Desa Jelun, Desa Kluncing, Desa Licin, Desa Pakel, Desa Segobang dan Desa Tamansari. Masing-masing desa memiliki potensi baik berupa pariwisata, nuansa Alam, Cagar Budaya, Adat Istiadat, Kegiatan Agama dan badan usaha yang dikembangkan oleh masing-masing desa sesuai dengan keterampilan dan sumber daya manusia yang dimiliki. Wujud dari tersebut adalah harapan membaiknya perekonomian masyarakat setempat.

\section{Desa Banjar}

Pengelolaan wakaf di Desa Banjar dilakukan oleh masjid desa. Bentuk pengelolanya terbagi menjadi beberapa bagian. Pertama tentunya wakaf berupa tanah dan bangunan masjid. Tanah bangunan masjid adalah wakaf utama. Karena dari tempat inilah pusat kegiatan masyarakat terbentuk dan tertata. Kedua wakaf masjid didapat dari wakaf pohon kelapa masyarakat. Wakaf ini hanya berupa pohon dan buah tidak termasuk tanah. Wakaf pohon kelapa bagi masyarakat desa sudah menjadisuatu yang lumrah dan sering dilakukan bukan hanya di desa Banjar tapi hampir diseluruh desa dikematan Licin atau bahkan di setiap desa se Indonesia.

Pengelolaannya dilakukan dengan memberikan tanggung jawab kepada masyarakat tertentu yang sudah diberikan mandat dan mempertimbangkan keadilan, amanah dan faktor ekonomi. ini dilakukan untuk membantu masyarakat sekitar aar memiliki kegiatan dalam melangsungkan kehidupannya dan menjadi daya tarik untuk bisa istiqhomah kemasjid.

Selain wakaf berupa bangunan dan tanah masjid,wakaf juga berupa pohon kelapa, dan area perasawahan. Sawah yang dikelola badan wakaf berjumlah 3 (tiga) lokasi. Pertama tempatnya ada di dusun krajan desa banjar. Kedua, tetap di desa banjar namun di dusun salakan. Sedang yang ketiga berada di desa licin. Sawah ini di kelola dalam bentuk tanaman polo ijo ${ }^{18}$ bentuk pengelolaannya adalah memperkerjakan buruh dari masyarakat setempat dengan perhitungan bagian adalah $20 \%$ untuk pengelola.

18 Tanaman sejenis Sayuran dan tanaman selain makanan pokok

$314 \mid$ JURNAL LISAN AL-HAL 
melihat dari pemaparan diatas dapat dipersentasikan pengembangan wakaf melalui persentasi sebagai berikut;

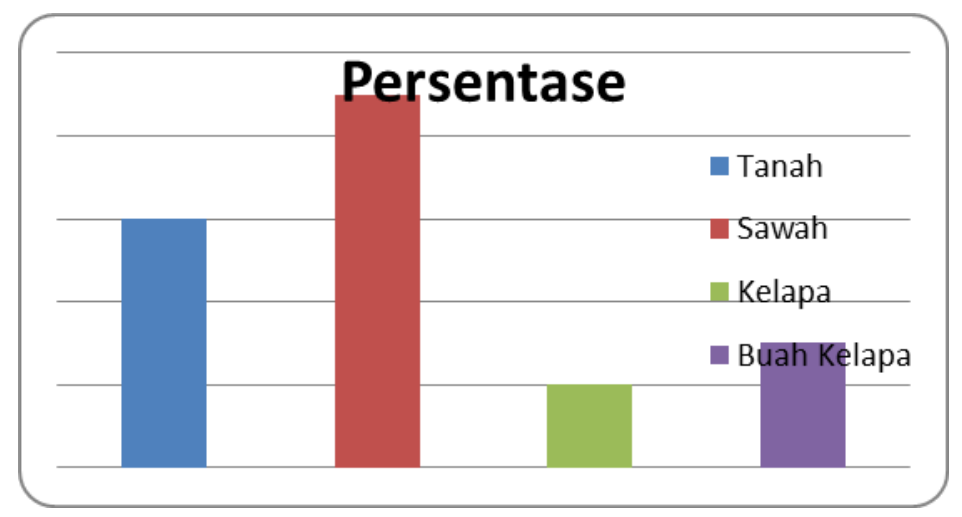

Gambar: Persentasi Wakaf Desa Banjar

2. Desa Gumuk

Wakaf telah dikelola dengan cukup baik di Desa Gumuk. Bapak H. Zainul Arin menyebutkan bahwa Masjid Desa Gumuk bisa dikatan menjadi pusat kegiatan yang cukup penting bagi masyarakat. Secara spesifik peneliti akan memaparkan tentang masjid sebagai tempat pengembangan ekonomi masyarakat dan pengembangan ekonomi mandiri masjid itu sendiri. tersebut sebagaimana penuturan Bapak H. Zainul Arin.

"untuk mengelola ekonomi mandiri masjid dan ekonomi masyarakat. Masjid Babur Rahman mendapatkan dana rutin jum'atan. Yakni melalui jariah sebelum pelaksanaan sat jum'at."19

Dana menjelang pelaksanaan sholat jum'at yan didapatkan ini berupa jariah jama'ah sholat jum'at. Selain itu didapatkan dari pengembangan Badan Wakaf Masjid. Lembaga ini secara khusus dibentuk oleh pengurus takmir masjid guna mengembangkan wakaf masyarakat.

"Kami memiliki Lembaga Pengembangan Wakaf yang disebut Badan Wakaf Masjid."20

Fungsi lembaga ini adalah mengatur perwakafan agar lebih baik dan maksimal dan memberikan konstribusi yang maksimal terhadap masjid dan masyarakat. Beberpa wakaf yang ditangani oleh Badan Wakaf Masijid adalah area perkebunan. Jumlah perkebunan yang dikelolah sebanyak delapan lokasi dengan luas cukup berfariasi. ini sesuai dengan pernyataan bapak H. Zainul Arifin selaku ketua Badan Wakaf Masjid.

19 Wawancara, H. Zainul Arin, 13 Mei 2018

20 Wawancara, H. Zainul Arin, 13 Mei 2018 
"Hingga tahun ini masjid secara keseluruhan mendapat delapan area perekbunan dengan luas berfariasi." 21

Setiap lokasi dikelola dengan berbagai fariasi tanaman. Seperti salah satu kebun yang pengeelolaannya dilakukan dengan penanaman khusus buah-buahan tropis. Seperti durian, pisang, manggis dan beberapa buah lain. ini dilakukan untuk memaksimalkan pendapatan dan adan garan yang fokus terhadap tersebut. Dan hasilnyapun dapat dirasakan secara berkala. ini sebagaimana disampaikan Bapak Muhlis.

"teng mriki khusus wakaf buah-buahan. Kelawan taneman hang uwohe cepet. Koyo gedang, tales. Ono pisan hang tanemane rodo suwi koyo manggis, duren mbi duku (disisni khusus mengelola wakaf tanaman buah. Serta tanaman yang cepat panen. Seperti pisang, talas. Ada juga tanaman yang buahny cukup lama sepeti manggis, durian dan duku.) "22

Pengelolaan ini memang sengaja. Sebagaimana telah kami singgung diatas yakni untuk memaksimalkan pendapatan. Selain kebun khusus buah tropis. Juga ada kebun khusus tanaman tropis lain. Yakni kelapa. Meski disetiap kebun mesti ada kelapa yang di tenam. Namun di kebun ini secara menyeluruh didominasi oleh pohon kelapa. Bentuk pembagiannya adalah setiap sepuluh buah yang didapatkan makan satu buah kelapa milik penanggung jawab. ini sebagaimana pernyataan bapak hori.

"wit kerambit hang ditandur neng kene sekitar 120 wit. Hang setiap sepuluh kelopo uwohe iku. Kulo oleh sak kelopo. Kadang waktu panen raya kulo biso oleh 150-175 uwohe (pohon kelapa yang ditanam disini (Kebun) sekitar 120 pohon. Dimana setiap sepuluh buah kelapa saya mendapat satu buah. Kadang waktu panen raya saya bisa mendapat 150-175 buah.)."23

Pengelolaan perwakafan dengan menunjuk badan Wakaf masjid tentunya sangat membantu pengelolaan. Selain itu penanggung jawab yang diambil dari masyarakat dapat membantu meringankan perekonomian secara umum bagi mereka. Beberapa ketentuan yang diterapkan saat penunjukan penanggung jawab perkebunan adalah memperhatikan kejujuran dan faktor ekonomi.

Selain perekbunan yang jumla delapan. Badan wakaf masjid juga memiliki wakaf sawah. Yang lokasinga di dusun Leces. Sawanya hanya

21 Ibid...

22 Mukhlis (Penanggung Jawab Kebun). Wawancara. Tanggal 16 Mei 2018.

23 Bapak Hori (Penanggung Jawab Kebun). Wawancara. Tanggal 16 Mei 2018.

$316 \mid$ JURNAL LISAN AL-HAL 
satu dengan ukurang kurang lebih setengah hektar. Pengelolaannya juga sama dengan sistem bagi hasil bagi masyarakat. Dengan ketentuan 25\% untuk pengelola dan $75 \%$ untuk masjid.

Desa gumuk memiliki antusias masyarkat terhadap kegiatan keagamaan sangatlah tinggi. Ini terbukti dari pernyataan bapak $\mathrm{H}$. Zainuddin Amrori selaku Takmir Masjid Baituttamam.

"masyarakatdi daerah jelun sangat antsias sekalaiterhadap kegiatan religus. ini dapat dibuktkan seperti semaraknya peringatan hari besar Islam. Serta antusias masyarakat terhadap pelaksanaan sholat taraweh." 247

Antusias inilah yang menumbuhkan hubungan masyarakat sangat erat dan ada perasaan saling memiliki dan menjaga satu sama lain. Kegiatan keagamaan yang cukup tinggi dan respon masyarakat juga berdampak terhadap kesejahteraan masjid. Pengelolaan ekonomi mandiri masjid dilakuakn melalui beberapa . Pertama. Jariah setiap jum'at.

"salah satu pengelolaan ekonomi masjid didapt dari sumbangan sukarela setiap pelaksanaan menjelang sholat jum'at."18

Pernyataan dari H. Muhibbin diatas memberikan informasi bahwa jariah yang dilakukan setiap menjelang pelaksanaan sholat jum'at ataupun waktu-waktu lain, memiliki efektifitas terhadap keuangan masjid. Salain dari jariah sukarela masyarakat. Pengelolaan ekonomi masjid juga didapat dari pengelolaan wakaf.

Lanjut pemaparan beliau demikian:

"salin jariah. Masjid Baituttamam juga melakukan pengelolaan wakaf, yakni berupa pertama berupa lahan masjid dan yang kedua adalah sawah sawah." 19

Berdasarkan pernyataan $\mathrm{H}$. Muhibbin tersebut menunjukkan Masjid Baituttamam memiliki beberapa unsur pelaksanaan ekonomi mandiri yang dikelola guna mencukupi kebutuhan masjid atau bahkan juga kebutuhan masyarakat. Selain wakaf tanah dan bangunan, wakaf sawah adalah salah satu wakaf yang sangat produktif untuk dikembangkan.

Wakaf berupa sawah yang dikelola Masjid Baituttaman adalah sebuah sawah yang tempatnya berada tak jaus dari area pemukiman masyarakat yakni di dusun krajan. Berdasarkan penyampaian bapak $\mathrm{H}$. Muhibbin bahwa pengelolaan wakaf tersebut dilakuakn dengan cara bagi hasil. Luas sawah yang dikelola yaitu $2600 \mathrm{~m}^{2}$.

${ }^{24}$ Zainuddin Amrori (Ketua Takmir). Wawancara. Tanggal 20 Mei 2018.

19 Ibid. 
"saah yang dikelola oleh Masjid Baituttaman luasnya kira-kira $260 \mathrm{~m}^{2}$. Dengan perjanjian bagi hasil dimuka kesepakatan kepada orang yang kami tunjuk dan bisa dipercayai." 20

Selain area persawahan takmir Masjid Baituttaman juga mengemukakan bahwa Masjid Baituttaman meiliki wakaf lain selain sawah. Yakni wakaf kebun dan pohon kelapa. Jumlah kebun yang dikelola oleh Masjid Baituttamam sebanyak tiga lokasi yang semuanya ada di desa jelun. Penmgelolaannya tetap menggunakan sistem bagi hasil dengan masyarakat yang telah ditunjuk dan dapat dipercaya. ini senada dengan penyampaian $\mathrm{H}$. Zainuddin Amrori.

"tiga lokasi kebun yang dimiliki Masjid Baituttamam semuanya terletak di desa jelun. Dengan luas kira-kira $14600 \mathrm{~m}^{2}$. Ini secara keseluruhan."26

Dalam pernyataannya yang lain pengelolaanya dilakukan dengan sistem bagi hasil. Langkah yang ditempuh ini dilakukan agar memberikan konstribusi positif kepada masjid dan memberikan solusi ekonomi masyarakat. Kebun yang dikelola oleh Masjid Baituttamam memiliki konstribusi positif bagi masyarakat. ini dapat dibuktikan dengan salah satu penanggung jawab kebun yang menyatakan bahwa, dirinya sebelum diberi tanggung jawab oleh masjid mengelola kebun hanya buruh dengan penghasilan tidak tetap. Namun setelah diamanahi tanggung jawab kebun. Penghasilannya dapat meningkan dan dapat memberikan konstribusi positif kepada masjid.

Kontribusi kebun wakaf yang dikelola Masjid Baituttamam sangatlah besar. Pemasukannya tidak kurang dari dua juta setiap bulannya. Selain perkebunan, warga masyarakat juga banyak yang mewakafkan pohon kelapa. Jumlah pohon kelapa wakaf tidak kurang dari 280 pohon.

Masih sama dengan pengelolaan tanah maupun kebun. Pohon kelapa yang dikelola oleh Masjid Baituttamam berdasarkan konsep bagi hasil. ini dikarenakan sangat mudahnya sistem penglolaan dan mengutungkan kedua bela pihak. Bapak H. Zainuddn Amroni mengatakan bahwa pengelolaan wakaf pohon kelapa dilakukan dengan bagi hasil dan masyarkat yang mengelola mendapat upah yang pantas sehingga tidak merugikan kepada mereka dan juga tidak memberatkan masjid.

21 Zainuddin Amrori (Ketua Takmir). Wawancara. Tanggal 20 Mei 2018.

$318 \mid$ JURNAL LISAN AL-HAL 


\section{Desa Segobang}

Kegiatan keagamaan Desa Segobang disentralisir di Dusun Krajan. Lebih tepatnya di Masjid Baitur Rohim. Masjid ini didirikan dengan sokongan masyarakat dan bantuan dari perwakafan. Khusus mengenai perwakafan. Masjid Baitur Rohim mengelola wakafnya dengan du acara. Pertama dikelola oleh takmir masjid. Kedua dikelola oleh remas. ini sesuai dengan pernyataan $\mathrm{H}$. Fathur Rahman.

"Pengelolaan wakaf Masjid Baitur Rohim dikelola oleh dua bentuk.

Pertama dikelola takmir. Kedua dikelola Remas."37

Pengelolaan wakaf yang dikelola Takmir masjid adalah tanah dan bangunan masjid. Pengelolaannya dilakukan oleh kepengurusan ketakmiran. Dengan membag terhadap beberpa kepengurusan. ini meliputi peberdayaan dan pengembangan masjid.

Selain tanah dan bangunan Masjid Baitur Rohim meliki tiga area sawah produktif. Pertama. Satu area berada di utara masjid. Luas sawah ini sebesar seperempat hektar. Dikelola oleh pihak takmir yang telah ditunjuk melalui rapat takmir masjid. Bentuk pembagiannya adalah dengan system buruh. Yakni menggaji pihak pengelola wakaf sawah dengan ketentuan yang telah di sepakati. ini sebagaiman pernyataan Ust. H. Fathurrahman.

"sawah yang ada di sebelah utara dikelolah oleh salah satu pengurus takmir masjid. Dengan system penggajian yang telah ditetapkan melalui rapat"38.

Dua sawah yang lain terletak di dusun Bedengan dan di Desa Banjar. Luasnya sawah yang ada di Desa Banjar memiliki luas sama dengan sawah yang terletak di Utara Masjid yakni seperempat hektar. Sawah yang ada di Desa ini bentuk pengelolaannya dilakukan dengan system bagi hasil. Bentuk pengelolaanya dengan membagi setiap lima sak pendapat gabah, maka pengelola berhak dengan satu sak. ini sebagaimana penyataan bapak Humaidi pengelola sawah wakaf Masjid Baitur Rohim.

"sawah wakaf hang kulo kelola niki gadahe masjid Baiturrohim Segobang. Bentuk kesepakatane yoiku setiap limang karung gabah hang dihasilno, kulo oleh sak karung gabah (sawah wakaf yang saya kelola ini milik Masjid Baitur Rohim Segobang. Bentuk kesepakatannya yaitu setiap lima sak gabah yang dihasilkan. Saya mendapat satu sak gabah.)"28

37 Fathurrahman (Takmir Masjid). Wawancara. Tanggal 23 Mei 2018.

${ }^{28}$ Humaidi (Pengelola Wakaf Sawah). Wawancara. Tanggal 23 Mei 2018. 
Bentuk pengelolaan yang demikian adalah bentuk pengelolaan yang relative lebih aman dari pada bentuk pengelolaan system buruh. Pengelolaan yang dikembangakan oleh masjid Baitur Rohim memberikan kontribusi yang lebih banyak kepada masjid, karena jumlah pendapat sawah sangat maksimal disbanding system buruh.

Sawah ketiga yang dikelola oleh Masjid Baitur Rohim berada di Dusun Bedengan. Bentuk pengelolaanya sama dengan bentuk pengelolaan yang dilakukan dengan tanah wakaf yang ada di Desa Banjar. Yakni dengan system bagi hasil.

Selanjudnya pihak masjid juga mendapata pengembangan wakaf pohon kelapa. Kelapa yang diwakafkan mayarakat berjumlah 750 pohon. Semua pohon kelapa yang dimiliki masjid dikelola oleh masyarakat yang telah ditunjuk oleh takmir masjid. Rata-rata setiap tahunnya kira-kira 1.200 buah. Setiap sepuluh buah, pengelola mendapat satu buah.

Sebagaiman telah penulis paparkan diatas bahwa pengelolaan wakaf dilakukan dengan dua kepengurusan. Pengelolaan yang kedua dilakukan oleh Remas Masjid Baitur Rohim. Jenis wakaf yang dikelola lebih banyak pada bidang usaha produktif. Diantanra jenis usaha yang dikembangkan adalah Loket Pelayanan Terpadu. Imam Yahya sekreataris Remas Masjid Baitur Rohim menuturkan.

"pengelolaan loket pelayanan terpadu mengembangkan beberpa usaha. Yakini penjualan Pulsa All Operator, tagihan PLN dan Token Listrik"29

Bentuk penyediaan layanan ini dilakukan untuk memenuhi kebutuhan masyarakat. Sebagian kecil dari kebutuhan dan transaksi mereka sudah bisa dipenuhi melalui adanya Loket Pelayanan Terpadu. Kedua. Pengelolaan percetakan. Beberpa jenis bentuk usaha percetakan yang dikelola oleh Remas adalah Printing, cetak undangan, desain dan cetak bener dan cetak foto. Nasrul Hadi Ketua Renas Masjid Baitur Rihim menuturkan.

"Remas Juga mengembangakan usaha percetakan. Yaitu mulai

printing, cetak foto, cetak undangan serta desain dan cetak bener." 41

Untuk cetak benner bentuk pengelolaannya dilakukan dengan kerjasam dengan percetakan bener di Kabupaten Banyuwangi ini sebagaimana telah disampaikan oleh pemaparan lanjutan Nasrul Hadi. Keterbatasan modal dan tempat pengelolaan percetakan memang menjadi hambatan dasar pengembangan usaha percetakan Masjid Baitur Rohim.

${ }^{29}$ Imam Yahya (Sekretaris Remas). Wawancara. Tanggal 20 Mei 2018.

$320 \mid$ JURNAL LISAN AL-HAL 
Bentuk pemesanan undangan dan percatakan lain dapat dibilang memiliki tingkat pemesanan yang cukup tinggi. ini dapat dibuktikan dengan setoran bulan percetakan sebanyak 600.000 perbulan kepad kas masjid.

Selain percetakan yang dikembangkan pihak masjid. Melalui kerjasama dengan PT. Solusi Balad Lumampah. Melakukan kerjasama pengembangan Pendaftaran Pelaksanaan Ibadah Haji, Umroh dan Ziarah. Imam yahya menuturkan bahwa untuk tahun ini ada satu jama'ah haji yang akan diberangkatkan. Selain itu juga pelksanaan umroh sudah hamper tiga bulan sekali bias berangkat.

Beberapa fasilitas sudah disediakan secara langsung oleh pihak remas. Untuk menjaga keamanan dan kemudahan jama'ah yang hendak melakukan ibada haji dan umroh serta ziarah. Imam yahya menambahakan:

"Fasilitas dasar Keberangkatan jama'ah telah disiapkan oleh Remas.

Ha ini untuk menghilangkan keraguan jama'ah." 42

Bentuk fasilitas yang disediakan adalah seperti baju ihrom, tas, koper, dan beberapa kebutuhan lainnya. Bentuk pengembangan usaha yang lain adalah penjualan jamu. Jamu yang dijual adalah jamu sehat, alami dan dihasilkan dari masyarakat desa setempat. Jamu yang dijual sebagai pengembangan usaha remas memang belum produktif. Namun harapan untuk mengembangkan dan memperluas usaha terus dilakukan

Untuk mengembangkan usaha, hingga saat ini masih dalam pengembangan usaha adalah servis HP, Laptop dan computer. Usaha ini masih belum berkembang secara luas namun beberapa orang telah mengenal servis ini. Serta telah merasakan manfaat servis yang diadakan oleh Remas.

\section{Simpulan}

Berdasarkan pemaparan diatas, ada beberapa bentuk wakaf dan pengelolaannya. Yaitu berupa Wakaf tanah. Terdiri dari tanah dan tanah kebun. Sebagian dikelola dengan sistem bagi hasil bersama masyarakat dan sebagian lain dengan sistem upah. Selain itu ada juga bidang sawah yang disewakan kepada masyarakat. Selain itu juga berupa Wakaf pohon kelapa. Bentuk pengelolaannya terbagi menjadi dua, sistem penanggung jawab dengan bagi hasil saat panen. Pengelolaan kedua dilakukan secara pibadi (Intern Takmi Majid). Dan yang terakhir pengelolaan wakaf melalui penyediaan loket pelayanan masyarakat dengan aneka farian usaha.

42 Imam Yahya (Sekretaris Remas). Wawancara. Tanggal 20 Mei 2018.

$$
\text { JURNAL LISAN AL-HAL } \mid 321
$$


Diantaranya Jenis usaha yang dikelola adalah Pendaftaran ibadah Haji, Umroh dan ziarah. Pembayaran tagihan PLN. Penjualan token listrik, penjualan Pulsa All Operataor, percetakan, service HP, Laptop, dan Komputer serta penjualan jamu sehat natural. Dengan memanfaatkan tanah wakaf sebagai bentuk pengelolaan usaha adalah termasuk upaya peningkatan pemanfaatan wakaf sebagai bagian dari solusi kesejahteraan masyarakat. Pengelolaan dalam bentuk usaha terbilang baru dan suatu terobosan yang dikembagkan. Dan ini adalah suatu positif bagi penglola dan bagi masyarakat.

\section{DAFTAR PUSTAKA}

Ali, Muhammad Daud, Sistem Ekonomi Islam Zakat dan Wakaf, Jakarta: UI Press. 1998.

Direktorat Jenderal Bimbingan Masyarakat Islam Departemen Agama RI. Fiqh Wakaf. Jakarta: Departemen Agama, 2007.

Khan, Muhammad Akram. An Introduction to Islamic Economics. Pakistan: IIIT danInstitute of Policy Studies, 1994.

M. Zein, Satria Effendi, Problematika Hukum Keluarga Islam Kontemporer, cet. I, Jakarta: Kencana. 2004.

Peraturan Pemerintah Nomor 28 Tahun 1977 tentang Wakaf

sa'ad, Ahmad Muhammad.al-Malamih al-Asasiyah lil alaqah Baina Nidzamial-Waqf wa-Iqtishad (pengantar Teori)

Thabrani, Nawawi. Dinamikan Perwakafan dalam Peradaban Islam. Jember: Pustaka Radja. Cet-1. 2013.

Undang-Undang Nomor 41 Tahun 2004 tentang Wakaf dan Peraturan Pemerintah Nomor 42 Tahun 2006.

Undang-Undang Nomor 41 Tahun 2004 tentang Wakaf.

Wahyudi, Abdullah Tri. Peradilan Agama di Indonesia, Pustaka Pelajar, Yogyakarta, Cet. I, 2004, Mengutip dari Cik Hasan Bisri, Peradilan Islam dalam Tatanan Masyarakat Indonesia, Remaja Rasdakarya, Bandung, 1997.

Zuhaily, Wahbah, Fiqh Al-Islam Wa Adillatuhu, Juz 10, Damaskus: Daar elFikr, 2006.

$322 \mid$ JURNAL LISAN AL-HAL 